\title{
The Find of Pre-Viking Age Charred Grains from Fort-Settlement in Tartu
}

\section{Tvauri, Andres}

2016

Tvauri , A \& Vanhanen , S 2016 , ' The Find of Pre-Viking Age Charred Grains from

Fort-Settlement in Tartu ' , Estonian Journal of Archaeology , vol. 20 , no. 1, pp. 33-53 . https://doi.org/10.3176/arch

http://hdl.handle.net/10138/164322

https://doi.org/10.3176/arch.2016.1.02

unspecified

publishedVersion

Downloaded from Helda, University of Helsinki institutional repository.

This is an electronic reprint of the original article.

This reprint may differ from the original in pagination and typographic detail.

Please cite the original version. 


\title{
Andres Tvauri and Santeri Vanhanen \\ THE FIND OF PRE-VIKING AGE CHARRED GRAINS FROM FORT-SETTLEMENT IN TARTU
}

\begin{abstract}
From the occupation layer of settlement adjacent to Tartu fort, deposited at some point between the 7th to 9th centuries, a soil sample was taken. In addition to other finds, charred plant macrofossils were obtained. These consisted of eight taxa. Barley was the most common cereal. The second most numerous cereal was rye. Bread wheat and oat were minor components. Four peas and two broad beans were found in addition to the cereals. Three hazelnut fragments and one oak acorn were the only remains of collected plants. One grain remnant of Bromus sp. could not be identified to the species level.

Previously reported plant remains from the Iron Age sites of Kuusalu, Iru, Rõuge, Otepää, Soontagana, Valjaja, Tartu fort, Tartu settlement, Aindu and Linnaluuste I were compared with the current material. According to the finds, barley was the most common cereal during the first millennium AD. Rye became common during the Late Iron Age. Two oat finds are significant, because they represent the first Iron Age finds of the crop in Estonia. It is not clear, however, whether oat was cultivated or a weed in Tartu during the 7th-9th centuries. Broad beans were found for the first time in Iron Age Estonia.
\end{abstract}

Andres Tvauri, University of Tartu, 18 Ülikooli St., 50090 Tartu, Estonia; andres.tvauri@ut.ee Santeri Vanhanen, Department of Philosophy, History, Culture and Art Studies, Archaeology, University of Helsinki, P.O. Box 59, FI-00014 Helsinki University, Finland; santeri.vanhanen@helsinki.fi

\section{Introduction}

Up to now, only very limited information about plant use during the Late Iron Age (AD 550-1227) has been available in Estonia. Although large amounts of charred grains have been discovered in several sites, the systematic sampling of soil in order to find macrofossils has only recently begun in the research of Estonian prehistoric settlements.

According to the evidence, which includes the location of settlement sites and graves, fossil fields, agricultural tools, osteological and pollen data, etc., agriculture and cattle rearing were the main economic activities during the Late Bronze Age (1100-500 BC), Pre-Roman Iron Age (500 BC-50 AD), and Roman Iron 
Age (50-450) (Lang 2007, 95). In the Migration Period (450-550), Pre-Viking (550-800), and Viking Age (800-1050), the main sources of subsistence were field cultivation and animal husbandry; hunting and fishing were significant means of subsistence only in south-eastern Estonia (Tvauri 2012, 111). Plant cultivation and cattle rearing were the main sources of subsistence also in the Final Iron Age (1050-1227). Palynological and macrofossil data discovered earlier have shown that barley (Hordeum vulgare), wheat species (Triticum aestivum ssp. aestivum/compactum and turgidum), rye (Secale cereale), oat (Avena sativa), pea (Pisum sativum) and hemp (Cannabis sativa) were cultivated in the Late Iron Age (550-1227).

This article presents charred plant remains from wet-sieved soil samples gathered from Tartu at 36 Lossi St. This is the very first sample of charred grain that has been discovered in the settlement area of a fort and settlement complex, but it demonstrates the great potential of studying archaeobotanical samples in Estonia. We compare it with other contemporaneous finds in Estonia and the neighbouring countries. Additionally we give an overview of all macrofossil plant remains gathered from Late Iron Ages sites in Estonia up to the present time, because such an outline has not been published before. We will also discuss the possible presence of shifting cultivation and aim to summarize the current knowledge of the history of Iron Age cultivation in Estonia.

Tartu 36 Lossi St. site

In May 2011 a sewerage pipeline was installed in central Tartu, near the eastern corner of 36 Lossi St. building (Fig. 1). Archaeological monitoring was carried out by Andres Tvauri. The pipeline installation was conducted on the site of the outer bailey of the medieval building known as the Tartu Bishop's Castle (Fig. 2). Prior to the erection of the castle, a settlement site had stood on the spot, adjacent to the prehistoric fort of Tartu. During the monitoring works, an asphalt road lay in the excavation area, as it also does today. Up to $40 \mathrm{~cm}$ from the upper surface of the street consisted of modern pavement layers. Below pavement layers, layers of fill containing fragments of bricks, lime mortar, and clay reached until the depth of $80 \mathrm{~cm}$ from the street surface (Fig. 3). Below the fill, until the depth of $120 \mathrm{~cm}$ from street surface, a black layer containing abundant charcoal was discovered. Potsherds found from that layer indicated that this was the occupation layer of the settlement site from the second half of the first millennium. The layer is known already from previous excavations at Toomemägi - Toome Hill (see Tvauri 2001). The layer was clearly distinguishable in the southern profile of the trench. Underneath the layer of prehistoric occupation was an approximately $20 \mathrm{~cm}$ thick layer of brownish soil; under this, at the depth of approximately $140-150 \mathrm{~cm}$ from the ground surface, natural sand appeared. 


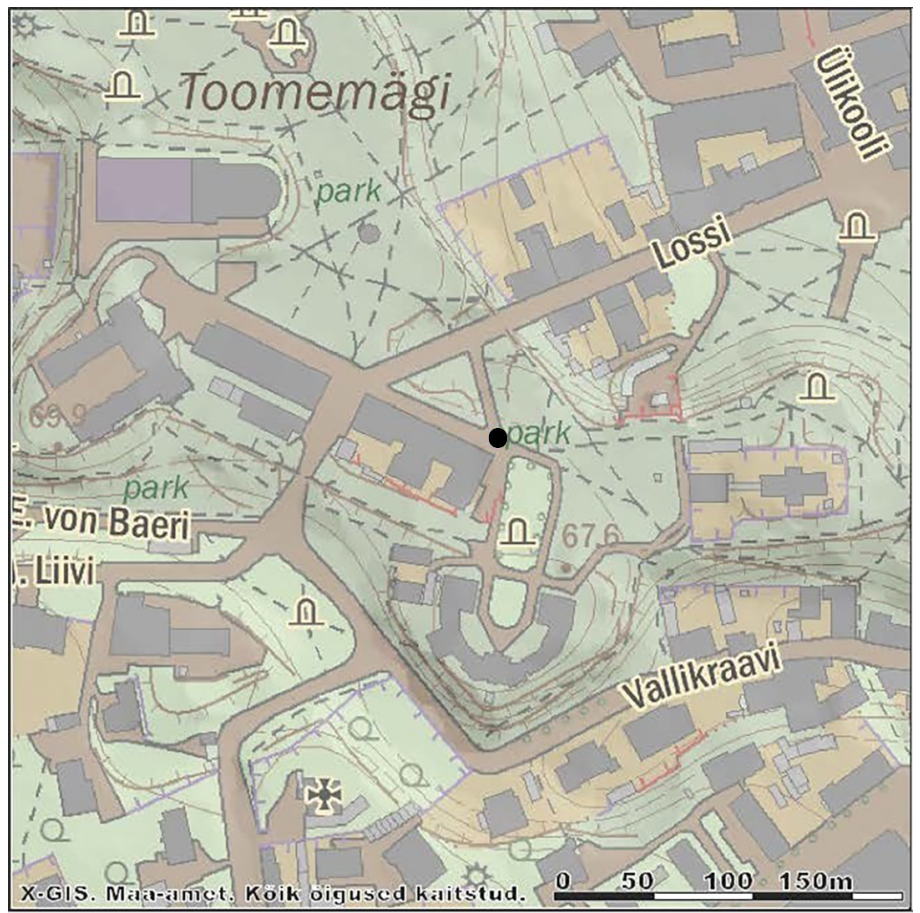

Fig. 1. General plan of the location of the charred grain finds.

A $2 \mathrm{~m}$ long section of occupation layer was displayed in the pipeline trench which was excavated by hand. The soil was stiff and dry in the upper part of the layer. A few sherds of Slavic-type wheel thrown earthenware dating from the 11th century (Tvauri 2012, 82 ff.) were obtained from there. Ceramics of such type are common in the occupation layer of Tartu fort and adjacent settlement site. The occupation layer dates from the period of approximately 1030-1061, a time when the fort was governed by the Grand Princes of Kiev (Tvauri 2001, $98 \mathrm{ff}$.). The lower part of the prehistoric occupation layer, approximately $15 \mathrm{~cm}$ thick, had a different composition than the upper one. It was doughy with abundant animal bones, fish bones, and scales. To obtain a representative amount of bone material, a 801 soil sample was taken from the lower part of prehistoric occupation layer. The material was wet sieved (mesh size $5 \mathrm{~mm}$ ). Although the original intention was to sieve out artefacts, animal bones, and fish remains, 254 charred grains and other plant remains ${ }^{1}$ were discovered while examining the material separated by sieving. Plant macrofossils were identified by Santeri Vanhanen.

${ }^{1}$ Bones and plant remains are preserved in the depository of the Archaeological Cabinet of the University of Tartu. 


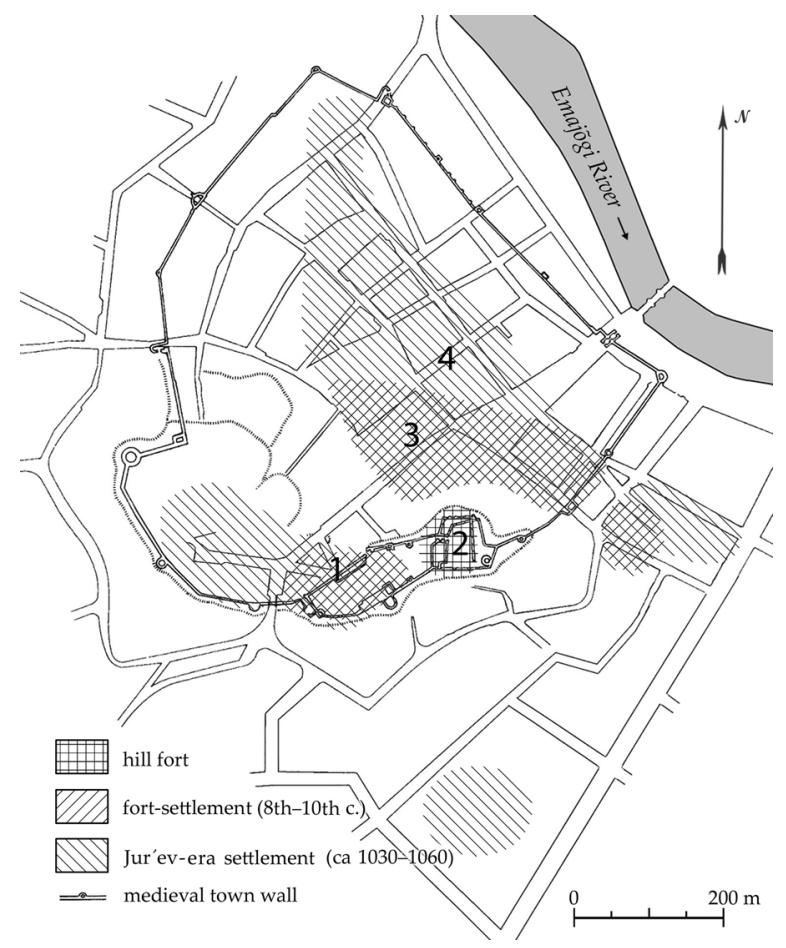

Fig. 2. Location of (1) charred grains in reference to (2) the Iron Age Tartu fort and settlement site. Other sites mentioned in the article are (3) 3 Lossi St. plot and (4) the excavation trench at the western part of Küüni St.

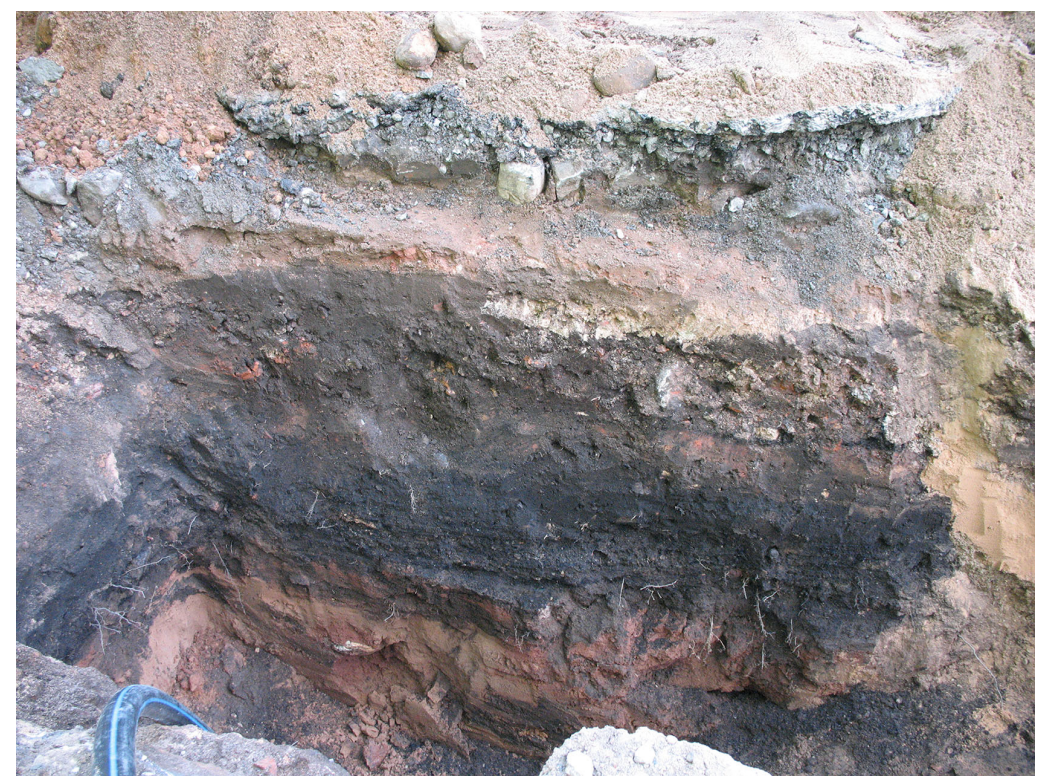

Fig. 3. Cross-section of strata in the find place of charred grains. Photo by Andres Tvauri. 


\section{Dating of charred plant macrofossils}

Among the artefacts obtained by sieving the soil sample, potsherds comprised the most numerous assemblage - all in all 563 fragments. The majority of these fragments (513 pieces) represent Rõuge-type pottery (Fig. 4). Fragments of handmade Rõuge-type clay vessels described above do not permit a more precise dating than to the 7th-10th centuries (Tvauri 2012, 77 f.). 50 sherds represent Slavic-type wheel thrown earthenware dating from the 11th century.

In addition to potsherds, other finds were obtained by sieving the soil. Among these was a spearhead fragment with a barbed head (Fig. 5). In Estonia and neighbouring countries, socketed and tanged barbed spearheads are dated to the 7th-8th centuries (Tvauri 2012, $192 \mathrm{f}$.). A more precise dating of the remaining artefacts is impossible as those artefact-types were used in Estonia throughout the period of 550-1250 AD. For example, three spherical glass beads were found. One of them (TM A 194: 27) was dark blue or black, one yellow (TM A 194: 28), and one white glass (TM A 194: 29) and three spherical clay beads (TM A 194: 24-26). Clay beads have been found in the cultural layers of several forts and settlements in Estonia, with the largest number having been found in the

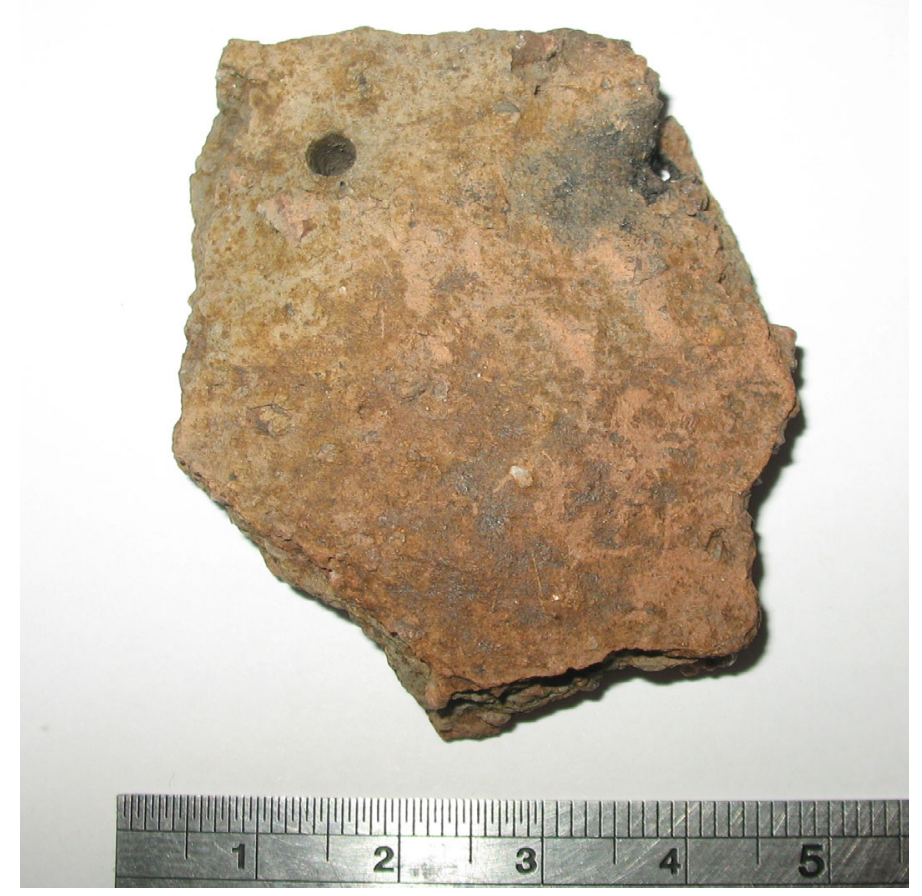

Fig. 4. Rõuge-type coarse ware (TM A 194: 92). Photo by Andres Tvauri. 


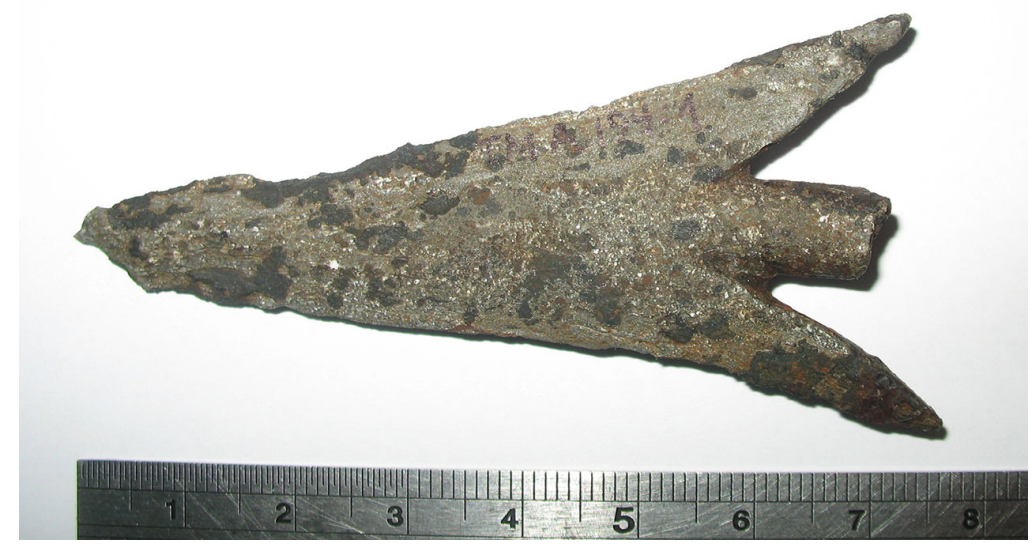

Fig. 5. Fragment of barbed spearhead (TM A 194: 1). Photo by Andres Tvauri.

Pre-Viking and Viking Age fort and settlement at Rõuge (Tvauri 2012, 148). Fragments of bronze wire and chain links originating from jewellery were also found (TM A 194: 5-14), and one little fragment of clay crucible (TM A 194: 23). Fragments of clay crucibles are common in Pre-Viking, Viking, and Final Iron Age forts and settlements in north-eastern, eastern, and southern Estonia (Tvauri 2012, 122). Drops of melted bronze (TM A 194: 15-20) also indicate bronze casting. Four pieces of flint (TM A 194: 31-34) used for lighting a fire were found as well.

Besides plant and animal remains, potsherds and artefacts, the layer contained numerous pieces of burnt stone debris and burnt clay. Based on this composition, the layer seems to consist of redeposited waste generated by food production, eating, and other activities. The homogeneous composition of the layer indicates that the layer had been deposited within a short period of time and that it has lain undisturbed afterwards.

AMS dates were obtained from two randomly chosen barley grains from the sample. The first one (Poz-59061) gave the result of 1260 \pm 25 BP, or 670-860 AD, with the calibration range probability of $95.4 \%{ }^{2}$; the second one (Poz-59062) gave the result of $1250 \pm 35 \mathrm{BP}, 674-875 \mathrm{AD}$, with the calibration range probability of $95.4 \%$.

The results of both dates are very similar which adds to the credibility of the dating. The dates also correspond with the dates of aforementioned artefacts. The only artefact find which can be dated more precisely - a fragment of spearhead

${ }^{2}$ Calibrated by OxCal v4.2 [20].; r5 (Bronk Ramsey 2013); IntCal13 atmospheric curve (Reimer et al. 2013). 
with barbed head (Fig. 5) - was dated to the 7th-8th century. As the occupation layer which was sieved was highly homogeneous and had probably deposited within a short period of time, one can date the entire assemblage of charred plant remains to the period of approximately $670-875 \mathrm{AD}$ or to the second half of the Pre-Viking Age.

\section{Plant macrofossils from the Pre-Viking Age occupation layer}

Altogether 254 charred plant macrofossils were identified (see Table 1, Fig. 6). These consisted of eight taxa.

Barley was the most commonly represented cereal, with 155 grains. Of these, 67 grains were further identified as hulled barley (Hordeum vulgare ssp. vulgare) and no remains of naked barley (H. vulgare var. nudum) were found. The second most numerous cereal was rye (Secale cereale) with 65 grains. Bread or club wheat (Triticum aestivum ssp. aestivum/compactum) was a minor component with seven grains. Only two grains of oat (Avena sp.) were identified. Pulse remains were found in addition to the cereals. These consisted of four peas (Pisum sativum) and two broad beans (Vicia faba). Three hazelnut fragments (Corylus avellana) and one oak acorn (Quercus sp.) were the only remains of collected plants. One seed of brome (Bromus sp.) was found, but could not be identified to the species level.

Table 1. Amount of charred plant material found at Tartu 36 Lossi St.

\begin{tabular}{lr}
\hline \multicolumn{1}{c}{ Charred plant remains } & Amount \\
\hline Cultivated plants & 67 \\
Hulled barley (Hordeum vulgare var. vulgare) & 33 \\
Hulled barley frag. (Hordeum vulgare var. vulgare) & 55 \\
Barley (Hordeum vulgare) & 54 \\
Rye (Secale cereale) & 11 \\
Rye frag. (Secale cereale) & 7 \\
Breadwheat (Triticum aestivum s.l.) & 2 \\
Oat (Avena sp.) & 14 \\
Cereal (Cerealia) & 4 \\
Pea (Pisum sativum) & 2 \\
Broad bean (Vicia faba) halve & 3 \\
Gathered wild plants & 1 \\
Hazelnut frag. (Corylus avellana) & \\
Oak acorn (Quercus sp.) & 1 \\
Arable weeds & 254 \\
Brome (Bromus sp.) &
\end{tabular}




\section{a}
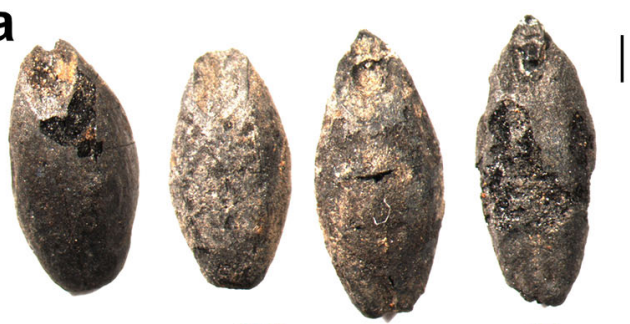

b
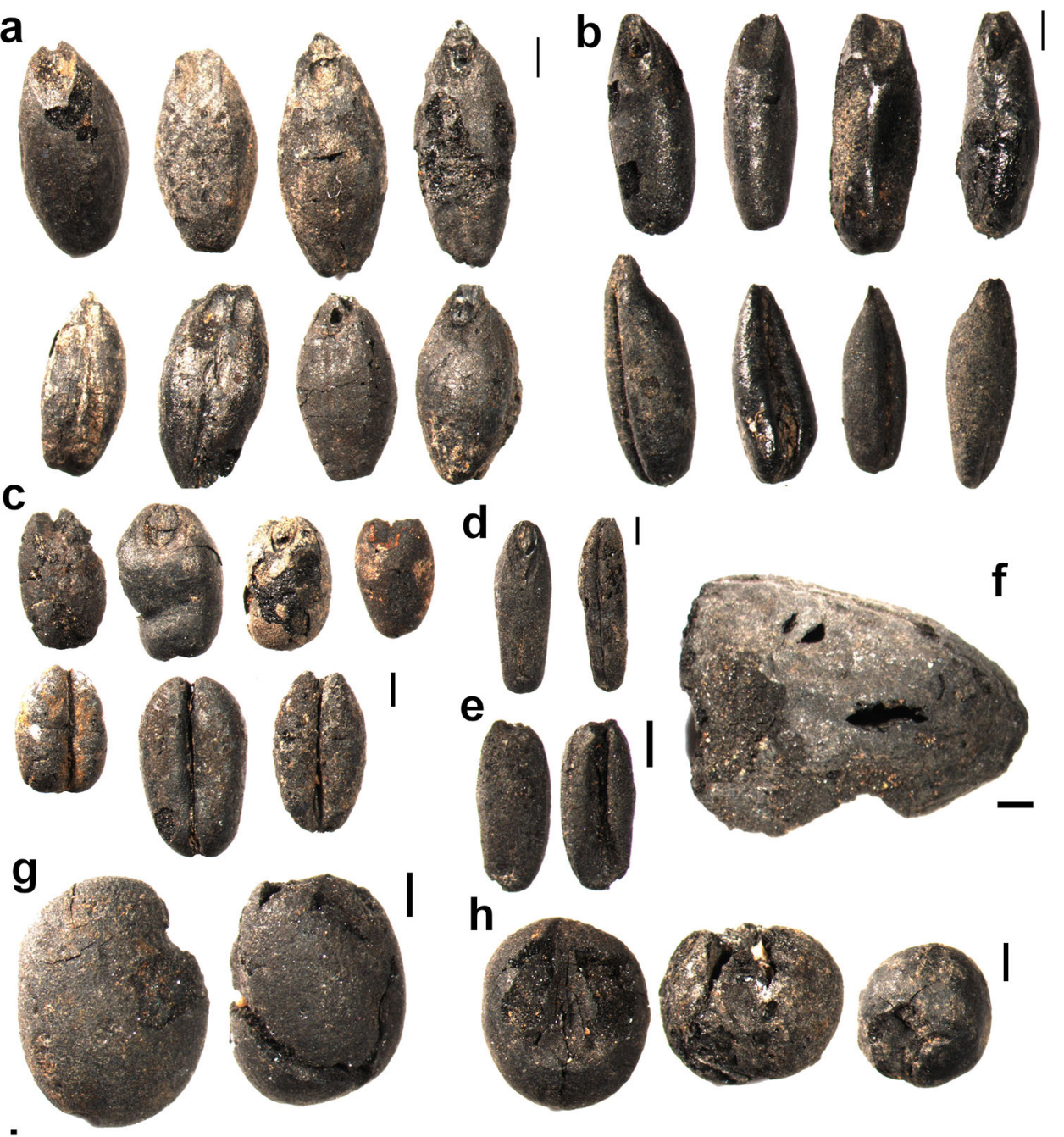

e
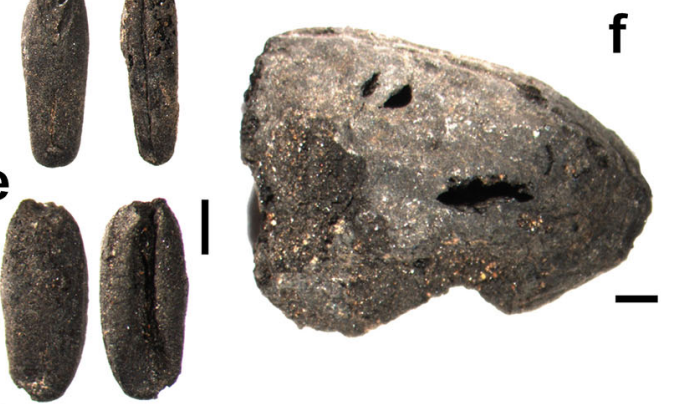

h
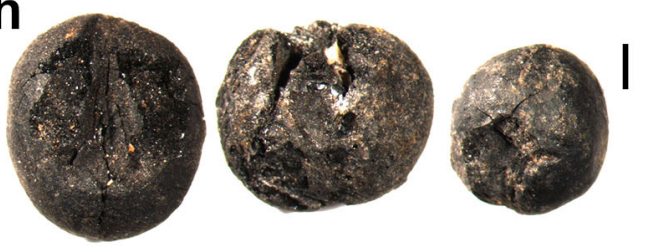

i

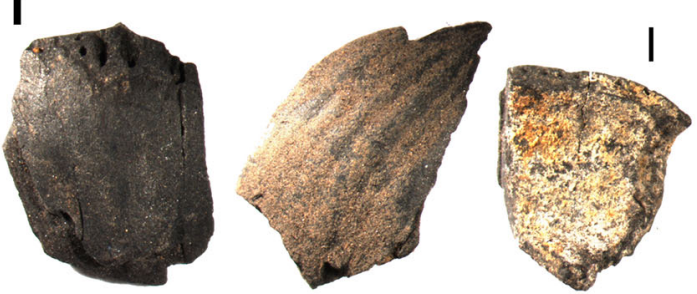

Fig. 6. Charred plant remains. a hulled barley (Hordeum vulgare ssp. vulgare), b rye (Secale cereale), $\mathrm{c}$ bread or club wheat (Triticum aestivum ssp. aestivum/compactum), d oat (Avena sp.), e dorsal and ventral views of the single brome grain (Bromus sp.), f oak acorn (Quercus sp.), g broad bean (Vicia faba), h pea (Pisum sativum), i hazel (Corylus avellana). Scale bars $=1 \mathrm{~mm}$. Photo by Santeri Vanhanen. 


\section{Finds of charred grains from the Estonian Iron Age sites}

The method of analysing charred grains emerged in Estonia already in the 1930s with the study of hill forts. That was the decade when charred grains and/or imprints of grains on pottery were studied at Asva fortified settlement in Saaremaa, Iru fortified settlement near Tallinn, and Kuusalu fort. The identification of Iru grains was done by Nikolai Rootsi (1888-1974), lecturer in the department of agriculture at the University of Tartu (Sillasoo 2005, 76). Archaeobotanical research continued in post-war archaeology, again in connection with the material from hill forts. The species of the grains and grain traces on potsherds from Asva, Iru, Kuusalu and Otepää hill forts were identified by the Latvian botanist Alfred Rasiņš (1916-1995) (Rasin'sh 1959a; Rasiņš \& Tauriņa 1983). Local scientists identified macrofossil remains found from certain sites at the request of the archaeologists who directed the excavations (Lõugas 1988, 18; Sillasoo 2005, 76; Kriiska \& Lõugas 2006, 227).

Nevertheless, charred grains have been identified only in cases when they have been discovered during field studies at forts or settlement sites. Until recently there have been no systematically collected archaeobotanical samples from the Estonian Iron Age sites. There is only one exception - soil samples were systematically gathered in the 1980s-1990s from the Pre-Viking and Viking Age occupation layer of the settlement that stood at the foot of Tartu fort. Those samples have been studied by paleobotanist Ülle Sillasoo, and also by Maria Abakumova, Mari Uudelt, and Mihkel Tammet (see Tvauri 2001, 81 ff.). The excavation of graves and fields of the second half of the first millennium has so far not documented the remains of cultivated plants. In Estonia, all macrofossil data are gathered from forts and settlements. Some of these have provided very impressive finds of burnt cereals discovered during archaeological excavations (Hiie 2010; Tvauri 2012, 102 ff.). Research has so far unfortunately been uncomprehensive. Only a brief overview about plant macrofossils found from the Estonian Late Iron Age sites has been published (Hiie 2010), which does not include all finds that exist and have been identified.

The largest find of grain in Pre-Viking and Viking Age sites in Estonia was uncovered at the fort at Kuusalu (Pajulinn) (Fig. 7: 2), where a 10-20 cm thick deposit of carbonized grain comprised at least $45 \mathrm{~m}^{2}$ of the excavation in 1938 . The grain presumably came from a burnt granary. It contained primarily barley and pea, but also some wheat and rye. The barley found at the fort at Kuusalu was mostly two-rowed (Hordeum distichon), with the four-row variant (Hordeum hexastichon) being less common (Schmiedehelm 1939, $131 \mathrm{f}$., fig. 81). The find assemblage of the fort can be dated to the 9th-10th centuries (Lang 1996, 326).

During the excavations at the hill fort of Iru (Fig. 7: 1) near Tallinn in 19361938, relatively large quantities of carbonized barley grains with a small amount of bread wheat, rye, and pea were found by the inner side of the northern rampart at the fort (Indreko 1936, 167, fig. 23). Pea seeds together with barley (Hiie 2010) 


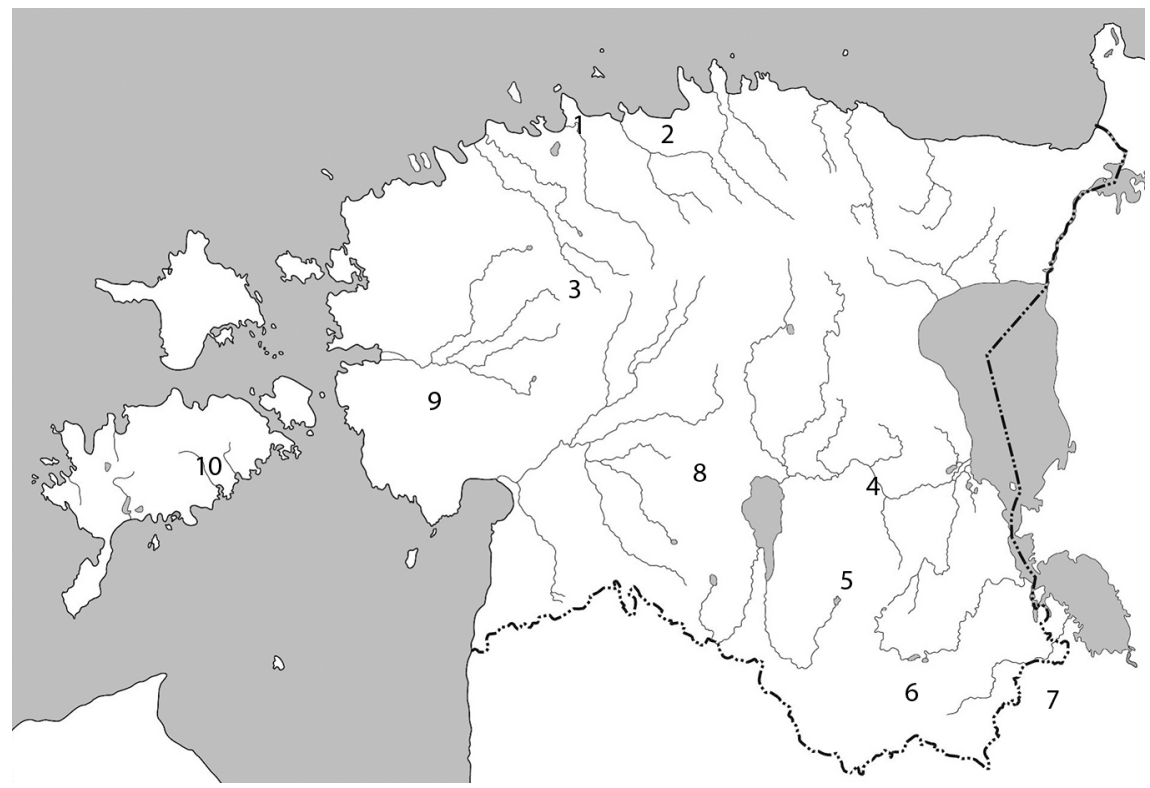

Fig. 7. Archaeological sites mentioned in the study. 1 Iru fort, 2 Kuusalu fort, 3 Linnaaluste I settlement site, 4 Tartu fort and settlement site, 5 Otepää fort, 6 Rõuge fort, 7 Izborsk fort, 8 Aindu settlement site, 9 Soontagana fort, 10 Valjala fort.

were also found a few metres from the spot of the first grain assemblage. Here the grain had probably been stored in clay vessels which broke when the fort was burning (Vassar 1939, 67, tab. V). Grains were obtained from the burnt layer of the second phase of occupation, dated to the years 900-950 AD (Lang 1996, 103). The same composition of grains was observed in the material from the excavations in 1952 and 1955 (Hiie 2010).

At Rõuge fort (Fig. 7: 6), where large-scale excavations took place in the years 1951-1955, carbonized barley grains were encountered in one of the excavated building remains, where grains had been stored in a clay vessel (Shmidekhel'm 1959, 159). Barley from Rõuge fort were of the four-row variant (Lepajõe 1986, 6). The find material from Rõuge fort has been dated to the 8th-11th centuries (Tõnisson 2008, 326). Ten radiocarbon dates obtained during the excavations in 2008 from the burnt layers inside the fort rampart indicate a rather long period of occupation from the end of the 6th to the end of the 10th centuries (Lillak \& Valk 2009, tab. 1).

Charred grains were also obtained from the fort at Otepää (Fig. 7: 5), in the course of excavations conducted in the 1950s, presumably from the occupation layer of the 11th-12th centuries (Rasin'sh 1959a, appendix 2). The dominant cereal was bread wheat, accompanied by small quantities of rye, barley, and oat (Rasin'sh 1959a, appendix 2; Hiie 2010). The occupation layer of the prehistoric fort of Otepää had been destroyed while erecting the medieval stone castle. Also, 
the documentation of the excavations at Otepää is so primitive that it is problematic to date grain finds specifically to the Late Iron Age. The found grains may just as well have originated from the Pre-Viking and Viking ages or from the Middle Ages.

The most impressive archaeological find of cereals was discovered in the fort at Soontagana (Fig. 7:9) in western Estonia during archaeological excavations in the years 1966-1971. Below the remains of ancient granary a 3-4 cm thick layer of charred grains was found, $95 \%$ of which was rye. Barley, more precisely two-rowed barley, was the next most common grain. The remaining grains were bread wheat. Some grains of emmer and durum-type wheat (Triticum turgidum) were also determined. Considering the apparent dominance of rye it has been assumed that wheat and barley got mixed with rye either during threshing or already in the granary (Tõnisson \& Lepajõe 1978, 29). Among the grains quite a large amount of rye brome (Bromus secalinus) seeds were found. As rye brome is a winter-hardy weed spreading with rye seeds it was assumed to be an indicator of the cultivation of winter rye (Tõnisson \& Lepajõe 1978, 29; Tõnisson 1992, 99; Hiie 2010). The director of the excavations at Soontagana, Evald Tõnisson, has dated the grain find to the 11th century based on the fact that the grain came from the lower layers of occupation debris (Tõnisson \& Lepajõe 1978, 30; Tõnisson 1992, 99). However, the abundant find material of the fort does not contain any artefacts that could be dated to a given period. As the Soontagana grain find is not radiocarbon-dated there is nothing to support the theory that its grains date to any other period than the dated artefacts which come from the 12th century or beginning of the 13th century.

Valjala fort (Fig. 7: 10) in Saaremaa was excavated in 1962. A foundation of a building with remains of a stove was unearthed in the fort yard. Approximately 10 charred rye grains were discovered between the stones of the stove base (Kustin 1963, 7). The stove remains and grains found from it have not been radiocarbon-dated. Considering that all find material gathered during the excavations (AI 4300) dates from the end of the Final Iron Age (the 2nd half of the 12th century and the 1 st quarter of the 13th century), and according to current knowledge Valjala charred grains also date to the same period.

Charred grains have been found during the excavations at Tartu fort in 1958 (Figs 2: 2, 7:4). The find contained primarily rye, but to a lesser extent also barley and bread wheat (Trummal 1964, 31). Along with the grains a quern-stone was found as well as other artefacts that can be dated to the period of approximately 1030-1061 when Tartu was a fort of the Grand Princes of Kiev.

At the foot of Tartu hill fort, on the damp flood-meadow of the Emajõgi River, stood Tartu settlement site that accompanied the fort. In the 1980s-1990s several soil samples were gathered from the prehistoric occupation layer in order to discover plant macrofossils. The layer had formed mainly during the years 1030 1061. Some deeper deposits of the occupation debris directly at the foot of the hill originate from Pre-Viking and Viking Age settlement layers (Tvauri 2001). Most of the samples did contain abundant remains of plants referring to natural conditions and connected with human activities but only an insignificant number 
of cultivated plant remains was discovered. From the 3 Lossi St. property (Fig. 2: 3) Mihkel Tammet gathered four soil samples taken from the prehistoric layer and found three charred grains of bread wheat (Tammet 1991). Soil samples from the western part of Küütri Street (Fig. 2: 4) revealed again remains of plant species of natural communities, as well as remains of barley and hemp (Cannabis sativa) (Sillasoo 1992).

Occasional cereal grains have been found at other settlement sites from the Late Iron Age, for instance at Aindu (Fig. 7: 8) in Viljandi county. Only one charred barley grain represented cultivated crops in the soil sample taken from the occupation layer during excavations in 1993. Some raspberry (Rubus idaeus) seeds were found in the lowest layers (Valk 1994b, 388). Finds and radiocarbon dates suggest that the settlement was established in the 9th century and was in use until the Middle Ages (Valk 1994a; 1994b).

During the excavations at the Linnaaluste I settlement site (Fig. 7: 3) near Keava fort in 2001, several carbonized grains of barley were found in what was probably a storage pit that was dated to about AD 690-970 on the basis of the charcoal obtained there (Konsa et al. 2002, 76; Konsa \& Kivi 2012, 71 f.).

\section{The Tartu find compared with other Estonian finds}

All the plant remains found in Tartu 36 Lossi St. consisted of cultivated or otherwise usable plants. This could be partly due to the methods used for retrieving the plant remains. Most of the weed species commonly found in archaeobotanical analyses tend to have small seeds (e.g. Chenopodium, Rumex, Persicaria), and thus they are difficult to find without floating soil samples and using sieves with small mesh sizes $(0.5$ or $0.25 \mathrm{~mm})$. As the grain find consisted of food waste, it is also possible that weed seeds were not present in this processing stage. The presence or absence of threshing remains and weeds cannot be, however, ruled out because of the sieving method.

The assemblage of cultivated species is typical for the period. Other Estonian Pre-Viking, Viking Age, and Final Iron Age sites contain mostly burned storage finds or large grain finds described in the previous chapter. In these the major components of the assemblage was barley, pea, rye, or wheat. This indicates that at least these cereals were cultivated. There are no previous finds of broad bean (Vicia faba) from Estonia. Triticum turgidum, representing most probably emmer (Triticum turgidum ssp. dicoccum) or spelt wheat (Triticum aestivum ssp. spelta) has only been previously found at one site and therefore seems to have been of minor importance.

The 36 Lossi St. assemblage adds oak to the list of known gathered plants. These were previously represented by the raspberry from Aindu (Valk 1994b, 388) and hazel, wild strawberry, and raspberry from Tartu Küütri St. (Sillasoo 1992). It should be noted, however, that gathered plants of the Iron Age were not systematically studied for this paper. 
It is notable that almost all the archaeobotanical assemblages derive from forts. The density of crops, namely cereals, seems to be greater in Pre-Roman hill forts in the Hesse region (Kreuz \& Schäfer 2008, 178). This could be true also for the Estonian assemblages, which in many cases contain large amounts of charred plant remains. Therefore, the plant material from the forts should be compared with the common settlement material to find out possible differences in composition and reveal whether these may have been consumer or producer sites. This should also be done by floating samples and sieving them with small mesh-sizes (preferably $0.25 \mathrm{~mm}$ ) in order to retrieve small seeds, threshing remains, and other small plant material. This way it would be possible to find out whether only cleaned grain is found in hill forts and if cereal processing happened in the settlements.

The composition of cereal crops and pulses seem to point towards a wellestablished agricultural practice that could have included shifting cultivation and some sort of horticultural elements. These crops have different qualities regarding soil, manuring, water-balance, and temperature. Diverse crop species afford farmers more security, because when some crops fail, others can survive.

Barley is present in nearly all Estonian Iron Age assemblages and it was indeed the crop of choice all around the Baltic especially during the first half of the first millennium AD. Barley tolerates poorer soils and climate than wheat (Zohary et al. 2012, 52, 57) and that may be one reason why it has been so extensively cultivated in northern latitudes. Hulled barley returns reasonable yields on manured plots even on poor soils (Welinder 1998, 194).

Rye cultivation is clearly evident in the Estonian assemblages, where it is a major component in two cases. Rye seems to have been developed into a crop from first being an arable weed; this happened in Europe during the Pre-Roman and Roman Periods (Behre 1992; Zohary et al. 2012, 65). In Tartu Lossi Street the amount of rye is relatively high and is clearly cultivated. Rye tolerates winter, does not require too much water and can grow on poor, acidic, and sandy soils (Behre 1992, 149; Zohary et al. 2012, 59). Rye is often cultivated on plots after barley, when most of the nutrients have been taken from the soil (Mikkelsen \& Nørbach 2003; Grabowski 2011, 481).

As indicated above, there is only a small amount of oat in the Tartu find: two grains. Both weedy and cultivated forms of oat existed in prehistoric times; it was probably a weed growing among barley and wheat before it turned into a cultivated crop (Barker 1985, 46; Zohary et al. 2012, 66 ff.). In the Estonian Iron Age find context, however, no oat grains have been found earlier and the first oat finds are from Otepää fort, dating to the 11th-12th centuries. Otepää oats have been identified as cultivated oat (Avena sativa), even though it is not reported whether floret bases have been found. The uninterrupted presence of oat pollen in the sediments of Lake Maardu, near Tallinn, for instance, nevertheless suggests that oat was cultivated throughout the second half of the first millennium. At the end of the Viking Age, oat cultivation even seems to have somewhat intensified, at least in the surroundings of Maardu (see Veski \& Poska 2004, table 2, fig. 5). 
The relative importance of oats in Estonia in the second half of the first millennium is difficult to assess due to lack of data, but in eastern Sweden, for instance, oat has been suggested to be an intentionally cultivated cereal during the Late Iron Age (Grabowski 2014, 14 and cited references). Similarly, in the 10th-11th-century layers of the fort at Izborsk (Fig. 7: 7), rye, barley, and wheat grains outnumbered the grains of oats, which made only a minor component of the assemblage (Kirianova 1981, table). Oat is less common than other cereals in the crop finds from Latvian forts from the 11th-13th centuries; oat grains did not dominate in any samples (Rasin'sh 1959a, 322). In Latvia, cultivation of oat is suggested to have begun in the 12th century (Rasiñš \& Tauriņa 1983).

All in all, based on the palynological data and archaeobotanical data from Tartu, it seems that oat was cultivated at least during the Middle Iron Age. During the Middle Ages and later, oat has been used as fodder, especially for horses (e.g. Vilkuna 2003). It could thus be possible that the assemblage from Tartu 36 Lossi St. contained mostly the remains of human consumption, thereby lacking plants used as animal fodder.

Wheat has been cultivated in Estonia ever since the beginning of crop cultivation in the Late Stone Age (Lang 2007, 33). Wheat imprints, together with barley and oat, have been found in the ceramics from the Bronze Age hill fort of Asva (Indreko 1939, 31; Lang 2007, 111 f.). Unfortunately the specific wheat species and type of oat have not been identified (Lang 2007, 112).

Bread wheat (Triticum aestivum ssp. aestivum) was a minor component of three of the grain finds from the forts of the second half of the first millennium $\mathrm{AD}$. The first find, where bread wheat is a major component, comes from Otepää fort, dated to the 11th-12th centuries. It remains unclear whether the wheat grew on fields as a separate culture or among barley. Separate finds of the different species accompanied by studies of arable weeds could shed light on this question.

Pulses fix nitrogen from the atmosphere and they could have been cultivated together with cereal crops, thus maintaining the soil fertility for longer periods of time. Pea was cultivated with wheat and barley already in south-west Asia, when these plants were domesticated for the first time (Zohary et al. 2012, 82 and cited references). Like oat, broad bean has been used as animal fodder (Zohary et al. 2012, 90).

Finds of both bread/club wheat and hulled barley show that the Tartu assemblage contained cereals that had to be handled in a different manner. Naked crops are removed easily from their chaff (Lister \& Jones 2012). Threshed naked wheats (e.g., bread/club wheat) are ready for storing or milling after winnowing and sieving (Zohary et al. 2012, 24). The removal of husks from hulled cereals (e.g. hulled barley) require more work (Lister \& Jones 2012, 440). The cultivation of hulled barley persisted in the north and was probably aimed mostly for animal fodder and malt production, whereas the earlier naked barley had mostly been used for human consumption (Lister \& Jones 2012, 444). 


\section{Introduction of the three-field system}

In the Iron Age Estonian permanent fields were mainly cultivated in a twofield system, where half the land was sown to crop and half left fallow. More advanced is a three-field system where the arable land of a farm or a village was divided into three large fields: one was planted in the autumn with winter crops, the second field was planted with summer crops, and the third was left fallow, in order to allow the soil of that field to regain its nutrients. By providing two harvests a year it reduced the risk of crop failure and famine. The possible adoption of the three-field system already before the 13th century has been discussed for 90 years in Estonia, Latvia, Poland, and north-western Russia (Tarvel 1969).

Based on indirect evidence from written and cartographic sources, Paul Johansen speculated in a study published in 1925 that the transition to the three-field system took place largely in the 2 nd half of the 13th century (Johansen 1925). In the 1920s and 1930s, Estonian history texts reflected Johansen's standpoint (e.g. Manninen 1933, 22; Moora et al. 1935, 158; Ränk 1935, 26; ENSV ajalugu, I, 1955, 75). This interpretation is based on circumstantial written evidence. A novel methodology was used by Russian archaeologist A. Kir'yanov. He considered the fact that certain weed species are only characteristic of permanent fields. Grain finds from the archaeological excavations in Novgorod led him to the conclusion that the three-field system was widely used in Novgorod land already in the 11th-12th centuries (Kir'yanov 1959, 330 ff.). Alfred Rasinš determined on the basis of rye brome finds from the Iron Age forts and settlement sites that the cultivation of winter rye in Latvia began at the turn of the 10th and 11th centuries (Rasin'sh 1959a, 326, 336). In known cases of the three-field system from the Late Middle Ages, the weed coefficient in rye is $0.13-0.28$. In archaeological grain finds from Latvia it is never above 0.05 and thus Rasinš deduced that the three-field system was more widely spread and regularly used in Latvia and neighbouring areas no earlier than the 13th century (Rasin'sh 1959b, 383).

In Estonia, rye brome seeds were discovered only in 1966-1971 in the charred grain find from Soontagana fort. Based on the rye brome find, Evald Tõnisson and Jaan Lepajõe determined that winter rye cultivation began in Estonia also in the 11th century and from that time onward the three-field system could be adopted (Tõnisson \& Lepajõe 1978). This opinion has reached later general interpretations of Estonian prehistory (Jaanits et al. 1982, 390; Tõnisson 1992, 98 ff.; Kriiska \& Tvauri 2002, $195 \mathrm{ff}$.).

To take rye brome seed finds from the end of the Iron Age as an indicator of winter rye should be considered with more caution for various reasons. First, the documentation of the finds is rather vague. Second, it is not clear whether rye brome in fact definitively indicates the cultivation of winter crops (Kreuz \& Schäfer 2011, 340). Third, rye brome could have been cultivated as a crop per se, at least during earlier periods, thus blurring its indicative value as a weed (Bakels 2014). It should still be noted that the presence of autumn/spring sown crops 
can be difficult to establish even with exceptionally preserved material, found e.g. in Danish iron-smelting furnaces (Henriksen 2003, 182), where winter rye cultivation is discussed.

Even if the evidence of rye brome is rather weak, based on the relatively equal amounts of rye and barley as major components (see above), it is highly possible that some sort of crop rotation has been conducted in the vicinity of Tartu in the 7th-9th centuries and in the Estonian fort sites since later stages of the Iron Age. The issue of crop rotation could be assessed with more certainty by studying floated soil samples and especially the weed assemblage in them, which is now unavailable (disregarding the finds of brome) due hand picking of the archaeobotanical material.

Valter Lang has already questioned whether the three-field system was in regular use in Estonia in the Final Iron Age (see Lang 1996, 497 f.). Straightforward written evidence of using the three-field system in both manors and farms only date from the beginning of the 16th century (Ligi 1963, $34 \mathrm{f}$;; 1992, 150).

\section{The content of grain find against the background of grain finds in the neighbouring countries}

According to Rasinšs, in Latvia until the 10th century barley dominated among grains and was grown as a spring cereal. Rye cultivation started to spread in the third quarter of the first millennium AD. In the find material of the 11th-12th centuries rye already prevails. It is suggested that mainly the winter variety was grown as rye brome often accompanies rye in grain finds. There are fewer wheat grains than there are of rye and barley. Until the end of the 12th century there is no proof of growing oat as a separate culture (Rasin'sh 1959a, 320; Rasiňš \& Taurina 1983).

In Finland barley was the main crop of the Late Iron Age assemblages. Rye was the second most important cereal and lost its weed status in the course of the Iron Age, when it seems to be cultivated alongside barley. It is not clear whether oat was cultivated. Bread wheat (Triticum aestivum s.1.) is rare and emmer wheat (T. dicoccum) even rarer. Flax (Linum usitatissimum), hemp, gold-of-pleasure (Camelina sativa), pea, and broad bean are found in few Late Iron Age contexts (Vanhanen 2012).

In southern Sweden the period of ca AD 400-800 is somewhat similar to the other regions. Hulled barley is the main crop also here. Rye, bread/club wheat, and oat are present in somewhat similar proportions. In addition to these, small amounts of speltoid wheats and naked barley were cultivated. In addition to cereals, also flax, gold-of-pleasure, broad beans, and peas were cultivated (Grabowski 2011).

In Denmark the situation is similar during the period of $300-750 \mathrm{AD}$, as hulled barley was the main crop and rye the second most important one. Here 
the difference is that oat is quite common. Minor crops were emmer, bread wheat, and naked barley. In addition millet, flax, peas, and hemp were cultivated (Robinson et al. 2009).

\section{Conclusions}

From the occupation layer of the settlement adjacent to Tartu fort, deposited at some point between the 7th and 9th centuries, a soil sample of approximately 80 litres was taken. The sample was wet-sieved. The layer contained mostly household waste. In addition to other finds, 254 charred plant macrofossils were obtained. These consisted of eight taxa. Barley was the most common cereal, with 155 grains; 67 of these were further identified as hulled barley and no remains of naked barley were found. The second most numerous cereal was rye with 65 grains. Bread or club wheat was a minor component with seven grains. Only two grains of oat were identified. Pulse remains were found in addition to the cereals. These consisted of four peas and two broad beans. Three hazelnut fragments and one oak acorn were the only remains of collected plants. One grain remnant of Bromus sp. could not be identified to the species level.

The charred grain remains from the settlement site at Tartu reaffirm the former knowledge, according to which barley was the main crop grown in what is today Estonia until the end of the 1st millennium. Rye starts to dominate in the crop finds only in the Late Iron Age.

Two oat grains are important because they are the first oat finds from the Estonian Iron Age context. Unfortunately, the grains cannot provide an answer to the question of whether oat was cultivated as a separate crop in the vicinity of Tartu in the 7th-9th centuries.

Pulses were an integral part of Iron Age agriculture. Peas have been found from two sites before. The broad bean find is the first one from Estonia so far and thus adds a new cultivated species for the Iron Age.

Finds of hazel and oak acorn show how gathering of wild plants was conducted in addition to crop growing.

The material from Tartu 36 Lossi St. is very promising. Further studies should concentrate on examining systematic soil samples from various types of sites to further elucidate the roles of producers and consumers and other aspects of the Iron Age agriculture in Estonia.

\section{Acknowledgements}

The study was financed by the Estonian Ministry of Education and Research (IUT20-7). Santeri Vanhanen received funding from the Doctoral Programme for History and Cultural Heritage. 


\section{References}

Bakels, C. 2014. The first farmers of the Northwest European Plain: some remarks on their crops, crop cultivation and impact on the environment. - Journal of Archaeological Science, 51, 94-97. http://dx.doi.org/10.1016/j.jas.2012.08.046

Barker, G. 1985. Prehistoric Farming in Europe. Cambridge University Press.

Behre, K.-E. 1992. The history of rye cultivation in Europe. - Vegetation History and Archaeobotany, 1, 141-156.

Bronk Ramsey, C. 2013. OxCal (computer program). Version 4.2. http://c14.arch.ox.ac.uk/ oxcal/OxCal.html

ENSV ajalugu, I. 1955. = Eesti NSV ajalugu, I. Ed. A. Vassar. Eesti Riiklik Kirjastus, Tallinn.

Grabowski, R. 2011. Changes in cereal cultivation during the Iron Age in southern Sweden: a compilation and interpretation of the archaeobotanical material. - Vegetation History and Archaeobotany, 20, 479-494.

Grabowski, R. 2014. Cereal Husbandry and Settlement. Expanding Archaeobotanical Perspectives on the Southern Scandinavian Iron Age. (Archaeology and Environment, 28.) Umeå.

Henriksen, P. S. 2003. Rye cultivation in the Danish Iron Age - some new evidence from ironsmelting furnaces. - Vegetation History and Archaeobotany, 12, 177-185.

Hiie, S. 2010. Finds of charred grains from Estonian hillforts. - 15th Conference of the International Work Group for Palaeoethnobotany; Programme and Abstracts. (Terra Nostra - Schriften der GeoUnion Alfred-Wegener-Stiftung, 2.) Berlin, 136.

Indreko, R. 1936. Iru linnus. - ERK, 7/8: 39/40, 138-175.

Indreko, R. 1939. Asva linnus-asula. - Muistse Eesti Linnused. 1936.-1938. a. uurimiste tulemused. Ed. H. Moora. Õpetatud Eesti Selts, Tartu, 2-52.

Jaanits, L., Laul, S., Lõugas, V. \& Tõnisson, E. 1982. Eesti esiajalugu. Eesti Raamat, Tallinn.

Johansen, P. 1925. Siedlung und Agrarwesen der Esten im Mittelalter. Ein Beitrag zur estnischen Kulturgeschichte. (Verhandlungen der gelehrten Estnischen Gesellschaft, XXIII.) Dorpat.

Kirianova, N. А. 1981. = Кирианова Н. А. Зерновые материалы Изборска. - Краткие сообщения [Института археологии Академии наук СССР], 166, 109-114.

Kir'yanov, A. V. 1959. = Кирьянов А. В. История земледелия новгородской земли X-XV вв. Труды новгородской археологической экспедиции, II. Eds A. В. Арциховский \& Б. А. Колчин. (Материалы и исследования по археологии СССР, 65.) Издательство Академии наук СССР, Москва, 306-362.

Konsa, M. \& Kivi, K. 2012. Village at the foot of the fort: settlement sites I-III at Linnaaluste. Keava - "The Hand of the Sun". Ed. V. Lang. (EJA, Supplementary Series, 1.) Estonian Academy Publishers, Tallinn, 63-91.

Konsa, M., Lang, V., Lainemurd, I. \& Vaab, H. 2002. Archaeological excavations at settlement site I of Linnaaluste. - AVE, 2001, 74-81.

Kreuz, A. \& Schäfer, E. 2008. Archaeobotanical consideration of the development of Pre-Roman Iron Age crop growing in the region of Hesse, Germany, and the question of agricultural production and consumption at hillfort sites and open settlements. - Vegetation History and Archaeobotany, 17 (Suppl. 1), 159-179.

Kreuz, A. \& Schäfer, E. 2011. Weed finds as indicators for the cultivation regime of the early Neolithic Bandkeramik Culture? - Vegetation History and Archaeobotany, 20, 333-348.

Kriiska, A. \& Lõugas, L. 2006. Scientific methods in Estonian archaeology. - Archaeological Research in Estonia 1865-2005. Eds V. Lang \& M. Laneman. (Estonian Archaeology, 1.) Tartu, 269-291.

Kriiska, A. \& Tvauri, A. 2002. Eesti muinasaeg. Avita, Tallinn.

Kustin, A. 1963. Aruanne Valjala maalinna arheoloogilistest kaevamistest 1962. a. Tallinn. Manuscript in AI.

Lang, V. 1996. Muistne Rävala: muistised, kronoloogia ja maaviljelusliku asustuse kujunemine Loode-Eestis, eriti Pirita jõe alamjooksu piirkonnas, I-II. (MT, 4. Töid arheoloogia alalt, 4.) Eesti Teaduste Akadeemia Ajaloo Instituut, Tallinn. 
Lang, V. 2007. The Bronze and Early Iron Ages in Estonia. (Estonian Archaeology, 3.) Tartu University Press.

Lepajõe, J. 1986. Oder. Valgus, Tallinn.

Ligi, H. 1963. Põllumajanduslik maakasutus Eestis XVI-XVII sajandil. (Talurahva töö- ja võitlusradadelt, II.) Eesti NSV Teaduste Akadeemia Ajaloo Instituut, Tallinn.

Ligi, H. 1992. Põllumajanduslik tootmine. - Eesti talurahva ajalugu, I. Olion, Tallinn, 148-163.

Lillak, A. \& Valk, H. 2009. Archaeological trial excavations on the Rõuge hill fort, south-east Estonia. - AVE, 2008, 72-81.

Lister, D. L. \& Jones, M. K. 2012. Is naked barley an eastern or a western crop? The combined evidence of archaeobotany and genetics. - Vegetation History and Archaeobotany, 2013, 22, 439446.

Lõugas, V. 1988. Loodusteaduslike meetodite kasutamisest Eesti arheoloogias. - Loodusteaduslikke meetodeid Eesti arheoloogias. Artiklite kogumik. Eds A.-M. Rõuk \& J. Selirand. Tallinn, 9-25.

Manninen, I. 1933. Die Sachkultur Estlands, II. (Õpetatud Eesti Seltsi eritoimetused, II.) Tartu. Mikkelsen, P. H. \& Nørbach, L. C. 2003. Drengsted. Bebyggelse, jernproduktion og agerbrug i yngre romersk og ældre germansk jernalder. Moesgård Museum \& Jysk Arkæologisk Selskab, Højbjerg.

Moora, H., Laid, E., Mägiste, J. \& Kruus, H. 1935. Eesti ajalugu, I. Esiajalugu ja muistne vabadusvõitlus. Eesti Kirjanduse Selts, Tartu.

Ränk, G. 1935. Vana-Eesti rahvakultuur. (Elav teadus, 41.) Eesti Kirjanduse Selts, Tartu.

Rasin'sh, А. Р. 1959a. = Расиньш А. П. Культурные и сорные растения в материалах архелогических раскопок на территории Латвийской ССР. - Вопросы этнической истории народов Прибалтики: по данным археологии, этнографии и антропологии. Под редакцией С. А. Таракановой и Л. Н. Терентьевой. Издательство Академии наук СССР, Москва, 316-339.

Rasin'sh, А. P. 1959b. = Расиньш А. П. Сорняки зернового археологического материала как показатель системы земледелия в Латвии до XIII века н. э. - Доклады научной конференции по защите растений. Акад. наук Литов. ССР, Ин-т биологии, Вильнус, 369-385.

Rasiṇš, A. \& Tauriṇa, M. 1983. Pārskats par Latvijas PSR archeoloǵiskajos izrakumos konstatētajām kultūraugu un nezālu sēklām. - Archeolog̣ija un Etnogrāfija, XIV, 152-175.

Reimer, P. J., Bard, E., Bayliss, A., Beck, J. W., Blackwell, P. G., Bronk Ramsey, C., Grootes, P. M., Guilderson, T. P., Haflidason, H., Hajdas, I., Hatté, C., Heaton, T. J., Hoffmann, D. L., Hogg, A. G., Hughen, K. A., Kaiser, K. F., Kromer, B., Manning, S. W., Niu, M., Reimer, R. W., Richards, D. A., Scott, E. M., Southon, J. R., Staff, R. A., Turney, C. S. M., van der Plicht, J. 2013. IntCal13 and Marine13 Radiocarbon Age Calibration Curves 0-50,000 Years cal BP. Radiocarbon, 55: 4, 1869-1887.

Robinson, D. E., Mikkelsen, P. H. \& Malmros, C. 2009. Agerbrug, driftsformer og planteressourcer i jernalder og vikingetid (500 f.Kr. - 1000 e.Kr.). - Danske Landbrugslandskaber gennem 2000 år. Fra digevoldinger til støtteordninger. Eds B. Odgaard \& J. R. Rømer. Aarhus Universitetsforlag, 117142 .

Schmiedehelm, M. 1939. Kuusalu Pajulinn. - Muistse Eesti linnused: 1936.-1938. a. uurimiste tulemused. Ed. H. Moora. Õpetatud Eesti Selts, Tartu, 121-138.

Shmidekhel'm, М. Kh. 1959. = Шмидехельм М. Х. Городище Рыуге в юго-восточной Эстонии. - Вопросы этнической истории народов Прибалтики: по данным археологии, этнографии и антропологии. Eds C. А. Тараканова \& Л. Н. Терентьев. (Труды Прибалтийской объединенной комплексной экспедиции, 1.) Академия наук СССР, Москва, 154-185.

Sillasoo, Ü. 1992. Taimeleiud Tartu Küütri tn. 1992. a. kaevendist (P. Piirits). Manuscript in the Institute of History and Archaeology of the University of Tartu.

Sillasoo, Ü. 2005. Mis saab arheobotaanikast Eestis? - EJA, 9: 1, 73-81.

Tammet, M. 1991. Tartu, Lossi t., 1985-1987 eraldatud arheobotaaniliste proovide analüüs. Tallinn. Manuscript in the Institute of History and Archaeology of the University of Tartu.

Tarvel, E. 1969. Kolmeväljasüsteemi hälvetest. - TATÜ, 1, 70-80.

Tõnisson, E. 1992. Külaühiskonna väljakujunemine. - Eesti talurahva ajalugu, I. Olion, Tallinn, $76-126$. 
Tõnisson, E. 2008. Eesti muinaslinnad. Eds A. Mäesalu \& H. Valk. (MT, 20.) Tartu, Tallinn. Tõnisson, E. \& Lepajõe, J. 1978. Teraviljakasvatusest Eestis 11.-13. sajandil (Soontagana maalinna leidude põhjal). - Tootmis-teadusliku konverentsi "Taimekasvatussaaduste kvaliteedi tõstmise ja teraviljakasvatuse ajaloo küsimusi" ettekannete materjale. Tartu, 28-34.

Trummal, V. 1964. Arheoloogilised kaevamised Tartu linnusel. (Eesti NSV ajaloo küsimusi, III. TRÜ Toimetised, 161.) Tartu.

Tvauri, A. 2001. Muinas-Tartu: uurimus Tartu muinaslinnuse ja asula asustusloost. (MT, 10.) Tartu, Tallinn.

Tvauri, A. 2012. The Migration Period, Pre-Viking Age, and Viking Age in Estonia. (Estonian Archaeology, 4.) Tartu University Press.

Valk, H. 1994a. Rescue excavations on the Late Iron Age settlement of Aindu. - TATÜ, 43: 1, 34-41.

Valk, H. 1994b. The end of excavation at the Late Iron-Age settlement of Aindu. - TATÜ, 43: 4, 386-389.

Vanhanen, S. 2012. Archaeobotanical study of a Late Iron Age agricultural complex at Orijärvi, eastern Finland. - Fennoscandia Archaeologica, 29, 55-72.

Vassar, A. 1939. Iru Linnapära. Muistse Eesti linnused: 1936.-1938. a. uurimiste tulemused. Ed. H. Moora. Õpetatud Eesti Selts, Tartu, 53-100.

Veski, S. \& Poska, A. 2004. Eelajalooline inimene ja pool-looduslikud taimekooslused Eestis pilk minevikku õietolmu meetodil. - Eesti Looduseuurijate Seltsi aastaraamat, 82. Tartu, 24-49.

Vilkuna, A. M. 2003. Financial management at Häme castle in the mid sixteenth century (1539 about 1570). - At Home within Stone Walls: Life in the Late Medieval Häme Castle. Eds T. Mikkola \& A.-M. Vilkuna. (Archaeologia Medii Aevi Finlandiae, VIII.) Turku, 15-132.

Welinder, S. 1998. Neolitikum-bronsålder 3900-500 f.Kr. - Det svenska jordbrukets historia Jordbrukets första femtusen år. Ed. J. Myrdal. Natur och Kultur, 11-236.

Zohary, D., Hopf, M. \& Weiss, E. 2012. Domestication of Plants in the Old World. The Origin and Spread of Domesticated Plants in South-West Asia, Europe, and the Mediterranean Basin. Fourth Edition. Oxford University Press.

\title{
Andres Tvauri ja Santeri Vanhanen \\ SÖESTUNUD VILJATERAD TARTU LINNUSEASULA EELVIIKINGIAEGSEST KULTUURKIHIST
}

\author{
Resümee
}

2011. aastal tegi Andres Tvauri arheoloogilist järelevalvet Tartus Toomemäel vee- ja kanalisatsioonitorustike paigaldamise juures. Lossi 36 hoone kirdenurga juures paljastus kaevises söene kultuurkiht, mis sisaldas suurel hulgal kalaluid ja -soomuseid, loomaluid ning põlenud kivide purdu. Kihi stratigraafilise asendi, leidude ja radiosüsinikumeetodil saadud kahe dateeringu põhjal pärineb kiht 7.-9. sajandist ning on jäänus Tartu muinaslinnuse kõrval paiknenud asulast.

Umbes 80 liitrit kihist märgsõeluti. Selle tulemusel koguti muu hulgas 254 söestunud taimejäänust, mille liigi määras Santeri Vanhanen. Jäänuseid oli kaheksast liigist. Kõige arvukamalt, 155 teraga, oli esindatud oder, millest 67 tera kuulusid harilikule odrale (Hordeum vulgare ssp. vulgare). Arvukuselt järgmine, 65 tera, oli rukis (Secale cereale). Hariliku nisu (Triticum aestivum ssp. aestivum/ compactum) ja kaera- (Avena sp.) teri saadi vaid kaks. Lisaks oli taimejäänuste 
hulgas neli söögiherne- (Pisum sativum) ja kaks põldoa- (Vicia faba) tera. Leiti ka kolm sarapuu- (Corylus avellana) pähkli katket ja tamme- (Quercus sp.) tõru katke. Umbrohtudest oli esindatud üks luste- (Bromus sp.) seeme, mida liigini määrata ei õnnestunud.

Varem on Eestis kogutud rauaaegsest kultuurkihist söestunud taimejäänuseid Kuusalu, Iru, Rõuge, Otepää, Soontagana, Valjala ja Tartu linnuselt, Tartu linnuseasulast ning Aindu ja Linnaaluste I asulakohalt. Käesolevas artiklis käsitletav leid kinnitab seniseid andmeid, mille põhjal otsustades oli kuni I aastatuhande lõpuni pKr Eesti alal peamiseks kultuurtaimeks oder. Rukis hakkas laiemalt levima alles hilisrauaajal.

Kaks kaeratera Tartu linnuseasula leius on olulised, kuna seni pole Eestis rauaaja muististest kaerateri leitud. Kahjuks ei ole nende abil võimalik kindlalt väita, et Tartu ümbruses kasvatati 7.-9. sajandil kaera. Ka söögihernes tuvastati Eesti rauaaja arheoloogiliste taimejäänuste hulgas esimest korda liigilise täpsusega. 